\title{
SENSITIVITY OF WECK'S REAGENT TO THE MICROSTRUCTURE INHOMOGENEITIES OF A PULSE-LASER-MODIFIED AlSi12CuNiMg ALLOY
}

\author{
OBČUTLJIVOST WECKOVEGA REAGENTA NA \\ MIKROSTRUKTURNE NEHOMOGENOSTI S PULZNIM LASERJEM \\ MODIFICIRANE ZLITINE AlSi12CuNiMg
}

\author{
Darja Steiner Petrovič́1, Roman Šturm² \\ ${ }^{1}$ Institute of Metals and Technology, Lepi pot 11, 1000 Ljubljana, Slovenia \\ ${ }^{2}$ University of Ljubljana, Faculty of Mechanical Engineering, Aškerčeva 6, 1000 Ljubljana, Slovenia \\ darja.steiner@imt.si \\ Prejem rokopisa - received: 2018-04-26; sprejem za objavo - accepted for publication: 2018-05-18
}

doi:10.17222/mit.2018.087

\begin{abstract}
In order to optimize laser cladding using pulsed-laser procedures, in particular to prevent failures of the cladding, a systematic $e x$-situ characterization can provide a lot of valuable information about the effects of the process parameters on the resulting microstructure and hardness. In this study, a $\mathrm{TiC} / \mathrm{TiB}_{2}$ cladded layer was produced by laser scanning over a pre-placed $\mathrm{TiC} / \mathrm{TiB}_{2} / \mathrm{Al}$ powder mixture on an aluminum alloy using a Nd:YAG pulsed laser. The increasing of the $E E D V$ (effective energy density per volume) influences larger scattering of the cladded-layer thickness, whereas the decreasing of the $E E D V$ influences the decrease of its surface roughness. The average hardness of the 0.1 -mm-thick layer was $400 \pm 10 \mathrm{HV} 0.3$, which confirmed an improvement in the mechanical properties of the surface. The microstructures were investigated using FE-SEM/EDS and light microscopy. An additional color chemical etching using Weck's reagent at room temperature was performed. Using color etching, the laser-affected features, i.e., the penetration depth, the melt pool, its boundaries and various inhomogeneities, could be clearly distinguished. The sensitivity of the color etchant to the morphological and compositional differences was confirmed by FE-SEM/EDS analyses and microhardness measurements.

Keywords: aluminum, pulse laser, cladding, morphological inhomogeneity, Weck's reagent
\end{abstract}

Z namenom preprečevanja nastanka napak pri optimiranju laserskih postopkov oblaganja s pulznim laserjem nam sistematična ex-situ karakterizacija lahko nudi veliko dragocenih informacij o vplivu procesnih parametrov na razvoj mikrostrukture in trdote. $\mathrm{V}$ tej raziskavi smo na aluminijevo zlitino s pomočjo laserskega pretaljevanja prednanešene mešanice $\mathrm{prahu} \mathrm{TiC} / \mathrm{TiB} / \mathrm{Al}$ naredili oblogo $\mathrm{TiC} / \mathrm{TiB}_{2}$. V postopku smo uporabili pulzni laser Nd:YAG. Povečevanje EEDV (efektivne gostote energije na enoto volumna) vpliva na večji raztros debelin obloženega sloja, zmanjševanje EEDV pa vpliva na zmanjšanje hrapavosti površine. Povprečna trdota $0,1 \mathrm{~mm}$ debelega obloženega sloja je $400 \pm 10 \mathrm{HV} 0,3$, kar potrjuje izboljšanje mehanskih lastnosti površine. Mikrostrukture smo preučevali z uporabo tehnik FE-SEM/EDS in svetlobno mikroskopijo. Pri sobni temperaturi smo izvedli dodatno barvno kemijsko jedkanje z Weckovim reagentom. Z uporabo barvnega jedkanja lahko razkrijemo številne nehomogenosti, ki so posledica vpliva laserske obdelave, npr. globino penetracije, bazen taline, njegove robove... Občutljivost barvnega jedkala na morfološke razlike smo potrdili $\mathrm{z}$ analizami FE-SEM/EDS in meritvami mikrotrdote.

Ključne besede: aluminij, pulzni laser, oblaganje, morfološke nehomogenosti, Weckov reagent

\section{INTRODUCTION}

When aluminum alloys are to be used for specific applications where a high hardness, special strength, good wear resistance, etc., are needed, an additional surface protection of the alloys is essential. For several decades laser surface engineering (LSE) has been used for a wide range of applications in order to modify and improve the microstructure and properties of metallic materials in a highly controllable way. ${ }^{1-9}$ In one of the techniques of LSE, the laser cladding is verified as being an effective and economical method for the in-situ synthesis of advanced coating materials with a rapidly solidified, refined microstructure and the production of advanced coatings. ${ }^{2,10-13}$

To increase the hardness of the surface layer of aluminum alloys a laser cladding with a ceramic mixture of
TiC and $\mathrm{TiB}_{2}$ can be applied. ${ }^{14-19}$ The average microhardness of $\mathrm{TiC}$ and/or $\mathrm{TiB}_{2}$ coatings is higher than the substrate's hardness, and the coatings show a better wear resistance. ${ }^{2,15-18}$ For a higher content of $\mathrm{TiB}_{2}$ in the ceramic components, the flexural strength of the coated aluminum specimens is increased, thus delaying the occurrence of the first crack in the coating or the occurrence of delamination. ${ }^{17}$ Furthermore, the corrosion resistance of the laser-cladded specimens is better than the substrate. ${ }^{18}$ It was reported that chemical reactions between $\mathrm{TiB}_{2}$ and liquid aluminum have not been observed during the process of laser cladding. The obtained microstructure showed $\mathrm{TiB}_{2}$ dispersed in $\alpha$-Al dendrites and an $\alpha-\mathrm{Al}+\mathrm{Si}$ eutectic. ${ }^{15}$ On the other hand, a small proportion of $\mathrm{TiC}$ dissolves in the melt, resulting in a microstructure composed of $\mathrm{TiC}$ and $\mathrm{Ti}_{3} \mathrm{SiC}_{2}$ particles 
dispersed in a matrix consisting of pro-eutectic $\alpha$-Al dendrites and an $\alpha$-Al+Si eutectic. ${ }^{16}$

The cladding process depends on several experimental parameters that must be optimized to generate tracks of high quality. Therefore, the characterization of the produced clads is essential for process control. In the characterization of coatings produced using the lasercladding technique, laser-induced breakdown spectroscopy (LIBS) has been proven to be a suitable tool, especially for materials that exhibit an inhomogeneous distribution of elements. ${ }^{12}$

If an optimal clad layer (well-bonded, thick, dense and without cracks) is to be formed, the laser singletracks' geometrical characteristics, such as width, height, penetration depth, dilution and wetting angle, should be identified. As a guide, a laser-cladding processing map can be drawn. ${ }^{13}$

However, the visual determination of various inhomogeneities in laser-cladded and/or melted microstructures, e.g., compositional gradients and changes, is of great importance for producing more uniform clads, but this can be very challenging. In the scientific literature, there is no reference that reports the use of Weck's reagent as a color etchant for laser-surface-modified aluminum alloys. Therefore, the objectives of the present work are two-fold: (i) to investigate the effect of the pulsed laser's peak power density on the characteristics of the $\mathrm{TiC} / \mathrm{TiB}_{2}$ laser cladding and (ii) to evaluate the sensitivity of Weck's reagent to the microstructure inhomogeneities of the laser-modified AlSi12CuNiMg alloy, and to show that relevant information about the resulting microstructure can be obtained through the use of color etching.

\section{MATERIALS AND METHODS}

\subsection{Cladding powders and substrate alloy}

The cladding material was a mixture of $\mathrm{TiC}, \mathrm{TiB}_{2}$ and Al powders (60 w/\%, $20 w / \%, 20 w / \%$, respectively). Due to the differences in the melting points of the $\mathrm{TiC}$, $\mathrm{TiB}_{2}$ and the aluminum alloy, $\mathrm{Al}$ powder was added to achieve better bonding between the cladded layer and the substrate. ${ }^{17}$ The diameters of the powder particles were between $4 \mu \mathrm{m}$ and $8 \mu \mathrm{m}$.

The chemical composition of the selected substrate, a hypo-eutectic aluminum alloy AlSi12CuNiMg (EN AC 48000), is given in Table 1.

Table 1: Chemical composition of Al alloy substrate (w/\%).

\begin{tabular}{|c|c|c|c|c|c|}
\hline $\mathrm{Si}$ & $\mathrm{Mg}$ & $\mathrm{Cu}$ & $\mathrm{Ni}$ & $\mathrm{Ti}$ & $\mathrm{Al}$ \\
\hline 12 & 1.04 & 0.93 & 0.9 & 0.01 & Balance \\
\hline
\end{tabular}

The microstructure of the AlSi12CuNiMg alloy is composed of primary dendrites of $\alpha$-Al with an interdendritic network of $\alpha$-Al-Si eutectic. The thermodynamic calculations (TDC) of the stability of the equilibrium phases in the aluminum alloy were performed using the
ThermoCalc, TTA17 database. As confirmed by the TDC, various intermetallic compounds, e.g., $\mathrm{Al}_{3} \mathrm{Ti}$, $\mathrm{Al}_{3} \mathrm{Ni}, \mathrm{Al}_{7} \mathrm{Cu}_{4} \mathrm{Ni}$ and $\mathrm{Al}_{5} \mathrm{Cu}_{2} \mathrm{Mg}_{8} \mathrm{Si}_{6}$, are stable under equilibrium solidification conditions at room temperature.

The aluminum alloy was used in the as-delivered state, i.e., in the as-cast state with an additional homogenization heat treatment. The heat treatment involves hardening to maximum strength using a solution heat treatment at $520-530{ }^{\circ} \mathrm{C}$ for $5-10 \mathrm{~h}$, followed by quenching and artificial ageing at $150-175{ }^{\circ} \mathrm{C}$ for $15-5$ h. The obtained mechanical properties of the substrate are given in Table 2.

Table 2: Mechanical properties of Al substrate

\begin{tabular}{|c|c|c|c|}
\hline $\begin{array}{c}\text { Hardness } \\
\mathrm{HV} 0.3\end{array}$ & $\begin{array}{c}\text { Tensile } \\
\text { strength } \\
R_{\mathrm{m}} / \mathrm{MPa}\end{array}$ & $\begin{array}{c}\text { Yield strength } \\
R_{\mathrm{p} 0.2} / \mathrm{MPa}\end{array}$ & $\begin{array}{c}\text { Elongation } \\
A_{5} / \%\end{array}$ \\
\hline $120 \pm 1$ & 280 & 240 & 1 \\
\hline
\end{tabular}

The dimensions of the aluminum-alloy substrates prepared for the laser cladding were $(65 \times 20 \times 2.5) \mathrm{mm}$. The specimen surface was ground using 800 -grit emery paper prior to applying the cladding mixture to the surface in order to eliminate the existence of the thick oxides. A thin layer of pre-paste powder mixture (with an approximate thickness of $h=0.15 \mathrm{~mm}$ ) was applied to the substrate surface with an air gun. For better adhesion of the powders to the substrate surface, the cladding powders were mixed with alcohol to form a wet paste.

\subsection{Laser surface cladding}

An approach using a pulsed, low-power Nd:YAG laser was chosen to investigate the suitability of this technique for the surface cladding. The procedures using a pulsed Nd:YAG laser could act as a cost-effective tool for advanced surface engineering or when an effective repair procedure for the damaged surface during its exploitation is needed, or both. ${ }^{6,19}$

The laser surface cladding was performed on specimens using an OR Laser, type: ECO BU80 Nd:YAG laser, with a maximum mean power of $80 \mathrm{~W}$ and a

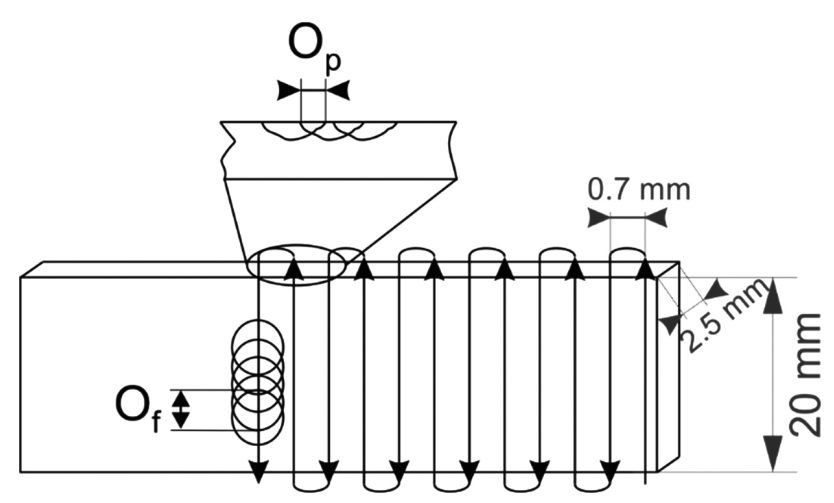

Figure 1: Laser treatment on the substrate 
top-hat mode structure, using the following experimental parameters:

- Average pulse power: $P_{\mathrm{a}}=46.5 \mathrm{~W}$

- Wavelength: $v=1064 \mathrm{~nm}$

- Frequency of pulse: $f=7 \mathrm{~Hz}$

- Pulse duration: $t_{\mathrm{p}}=8 \mathrm{~ms}$

- Maximum pulse power: $P_{\mathrm{p}}=0.83 \mathrm{~kW}$

- Pulse energy: $E_{\mathrm{p}}=6.64 \mathrm{~J}$

For this study, a combination of pulse duration and pulse frequency was chosen in such a way that the average power did not reach the limit of the Nd:YAG laser system used. A protective argon gas of $99.995 \%$ purity and a flow rate of $5 \mathrm{l} / \mathrm{min}$ was used during the whole process to minimize the surface oxidation. In our experiment we were changing the laser beam's travelling speed on the specimen's surface. The laser beam changed its movement at a distance of $0.7 \mathrm{~mm}$, as shown in Figure 1. The laser beam's parameters were:

- Beam travel speed: $v_{b}=100,150,200 \mathrm{~mm} / \mathrm{min}$

- Beam diameter on the specimen surface: $D_{\mathrm{b}}=1.0$ $\mathrm{mm}$.

As described elsewhere ${ }^{19}$ the following laser-processing characteristics can be calculated:

- Laser path overlapping: $O_{\mathrm{p}}=30 \%$,

where: $\quad O_{\mathrm{p}}=\frac{D_{\mathrm{b}}-\Delta x}{D_{\mathrm{b}}} \cdot 100 \%$

- Overlapping factor between laser pulses: $O_{\mathrm{f}}=54,65$ and $77 \%$,

where:

$$
O_{\mathrm{f}}=\left[\left(D_{\mathrm{b}}+v_{\mathrm{b}} \cdot t_{\mathrm{p}}\right)-\left(\frac{v_{\mathrm{b}}}{f}\right)\right] \cdot 100 \%=
$$

$$
=\left(1-\frac{v_{\mathrm{b}} / f}{D_{\mathrm{b}}+v_{\mathrm{b}} \cdot t_{\mathrm{p}}}\right) \cdot 100 \%
$$

Due to the nature of the pulsed beam, an effective energy density $(E E D)$ was calculated to determine the total energy input during the laser processing: ${ }^{19}$

$$
E E D=\frac{E_{\mathrm{p}} \cdot F}{A}\left(\mathrm{~J} / \mathrm{mm}^{2}\right)
$$

where $A\left(\mathrm{~mm}^{2}\right)$ is the area of laser spot on the specimen, $F$ is the cumulative overlapping index defined as:

$$
\begin{gathered}
F=1+n \cdot\left[1-\frac{(n+1) \cdot v_{\mathrm{b}}}{2 f \cdot D_{\mathrm{b}}}\right] \\
n=\frac{D_{\mathrm{b}} \cdot f}{v_{\mathrm{b}}}
\end{gathered}
$$

In a laser-cladding process the effective energy density per volume $(E E D V)$ of the pre-pasted powder is a more appropriate parameter for evaluating the results: ${ }^{20}$, 21

$$
E E D V=\frac{E E D}{h}\left(\mathrm{~J} / \mathrm{mm}^{3}\right)
$$

The calculated $E E D V$ is, according to different $E E D$ and $h$, in the range between $87 \mathrm{~J} / \mathrm{mm}^{3}$ and $146 \mathrm{~J} / \mathrm{mm}^{3}$.

\subsection{Metallography and chemical etching}

For the metallographic analyses the specimens were ground and polished in accordance with standard metallographic techniques. The metallographic analyses were performed using light microscopy and scanning electron microscopy. The field-emission scanning electron microscope was a JEOL JSM 6500-F equipped with an energy-dispersive spectrometer. The FE-SEM/EDS analyses were performed at a $10-\mathrm{kV}$ accelerating voltage. For the light microscopy we used a Nikon Microphot FXA microscope. No additional filters or analyzers were used.

In order to reveal the solidification microstructure Weck's reagent (i.e., $4 \mathrm{~g}$ of $\mathrm{KMnO}_{4}, 1 \mathrm{~g}$ of $\mathrm{NaOH}$ and $100 \mathrm{ml}$ of distilled water) was used for the chemical etching. The etching was performed at room temperature for $10 \mathrm{~s}$.

\subsection{Hardness and surface roughness}

The hardnesses of the clad layer and the base material were measured using a load of $300 \mathrm{~g}$ (HV 0.3) on metallographically polished cross-sections of the laser-cladded specimens. In addition, microhardness measurements were performed separately in the laser-

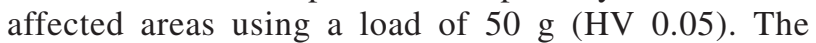
Vickers microhardness was measured using an Instron Wilson-Wolpert Tukon 2100B hardness tester. The measurements were performed in accordance with the Vickers method, i.e., a diamond-pyramid hardness measurement, through the depth of the alloyed layer. The dwell time of the test load was $12 \mathrm{~s}$.

The surface roughness $\left(R_{a}\right)$ was measured using a profilometer Surtronic 3+/TalyProfile Lite 3.1.4.,+, Taylor-Hobson, with a sampling length of $8 \mathrm{~mm}$ and a measurement speed of $0.5 \mathrm{~mm} / \mathrm{s}$. Five measurements on each sample were performed.

\section{RESULTS AND DISCUSSION}

The pulsed Nd:YAG laser, typically used for such welding, was chosen to investigate the suitability of this technique for the surface modification via laser surface cladding. In order to prevent various failures of the cladded coating, and for the optimization of the laserbased procedures, the identification of the penetration depth and the dilution zone is valuable information.

To reveal the laser-affected, sub-surface areas of the aluminum alloy more clearly, a systematic metallographic characterization was performed. Additionally, color chemical etching using Weck's reagent was performed. 


\subsection{Laser-cladded layer}

By varying the selected parameter, i.e., the effective energy density per volume $(E E D V)$ of pre-pasted powder $=(87,107$, and 146$) \mathrm{J} / \mathrm{mm}^{3}$, the laser-surface cladding of the aluminum alloy with the $\mathrm{TiC}+\mathrm{TiB}_{2}+\mathrm{Al}$ powder produced a characteristic microstructure, as shown in Figure 2.

Under different applied conditions, the thicknesses of the obtained $\mathrm{TiC} / \mathrm{TiB}_{2}$ layer were in the range from $0.03 \mathrm{~mm}$ to $0.15 \mathrm{~mm}$. The average thickness of the laser-cladded layer is around $0.1 \mathrm{~mm}$. The average hardness of the approximately $0.1-\mathrm{mm}$-thick $\mathrm{TiC} / \mathrm{TiB}_{2}$ laserclad layer is $400 \pm 10 \mathrm{HV} 0.3$. The average thickness of the melted aluminum beneath the laser-cladded layer is around $0.15 \mathrm{~mm}$, in the range between $0.05 \mathrm{~mm}$ and $0.22 \mathrm{~mm}$.

Table 3 presents the correlation between $v_{\mathrm{b}}, O_{\mathrm{f}}$, $E E D V$, and the thickness and roughness of the lasercladded surface. Taking into account the influence of laser beam's movement (see Figure 1) we can also observe a larger scattering of cladded-layer dimensions with the increasing of the $E E D V$, whereas the decreasing of the $E E D V$ influences the decrease of the surface roughness $R_{a}$ of the cladded surface.

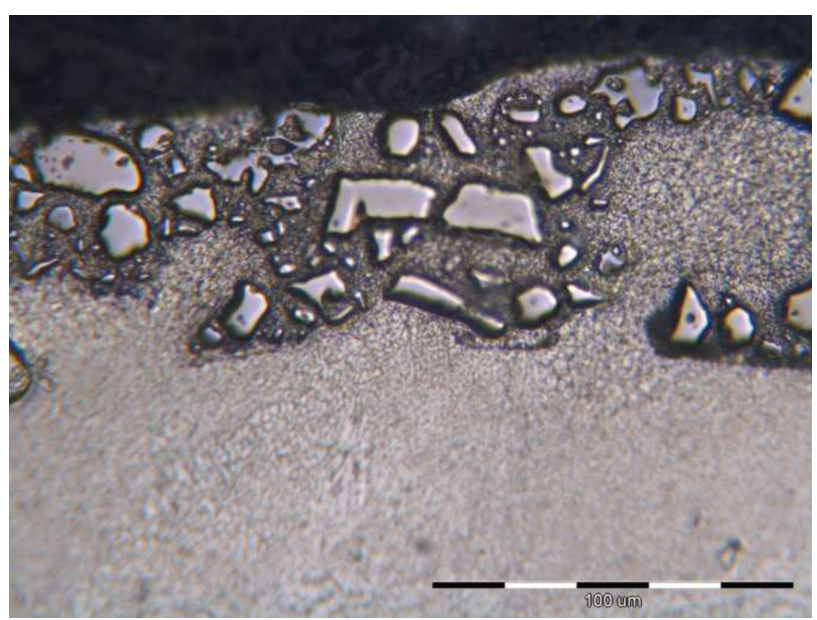

Figure 2: Laser-clad layer of $\mathrm{TiC}^{\mathrm{T}} \mathrm{TiB}_{2}$ on substrate. $E E D V=107$ $\mathrm{J} / \mathrm{mm}^{3}$
Table 3: Laser-cladding parameters and dimensions of the cladded surface

\begin{tabular}{|c|c|c|c|c|}
\hline $\begin{array}{c}v_{\mathrm{b}} \\
(\mathrm{mm} / \mathrm{min})\end{array}$ & $O_{\mathrm{f}}(\%)$ & $\begin{array}{c}E E D V \\
\left(\mathrm{~J} / \mathrm{mm}^{3}\right)\end{array}$ & $\begin{array}{c}\text { Cladded } \\
\text { layer thick- } \\
\text { ness } d(\mu \mathrm{m})\end{array}$ & $\begin{array}{c}\text { Surface } \\
\text { roughness } \\
R_{a}(\mu \mathrm{m})\end{array}$ \\
\hline 100 & 77 & 146 & $35-104$ & $11-17$ \\
\hline 150 & 65 & 107 & $50-95$ & $6-7$ \\
\hline 200 & 54 & 87 & $111-145$ & $3-5$ \\
\hline
\end{tabular}

\subsection{Metallographic analyses}

The produced clad layers are predominantly dense and thick. A typical microstructure of a laser-cladded $\mathrm{TiC} / \mathrm{TiB}_{2}$ layer on an aluminum specimen is shown in Figure 2. In the micrograph presented in Figure 2a well-bound, laser-clad layer of $\mathrm{TiC} / \mathrm{TiB}_{2}$ on an AlSi12CuNiMg substrate can be seen. In the clad layer, the powder is well mixed with the base material, or vice versa, the powder is incorporated into the remelted layer.

Using the pulsed-laser processing parameters, some discontinuities were revealed, depending on the sample's geometry. This was particularly significant in the laser-modified areas lying at the sample's edges.

In Figure 3a a discontinuity section is shown. Due to the fact that the area is near the sample's edge, the selected laser parameters produced different effects than on the bulk substrate (Figure 2). Through the selected cross-section, the chemical composition of the sample is very nonhomogeneous. Microchemical EDS analyses revealed the presence of $\mathrm{Ti}, \mathrm{B}$, and $\mathrm{C}$ on the surface clad-region and in some subsurface areas (Table 4). As can be seen in Figure 3a, an exact determination of the laser-affected zones is very challenging. Therefore, a color chemical etching using Weck's reagent was applied (Figure 3b).

A colored microstructure with an enlarged section of the discontinuity section of the laser-clad layer before and after color etching are presented in Figure 4.

The microstructures of the laser-treated materials that form during the re-solidification critically determine the properties. Microstructure variations in the subsurface laser-melted and affected Al-alloy substrate from Fig-

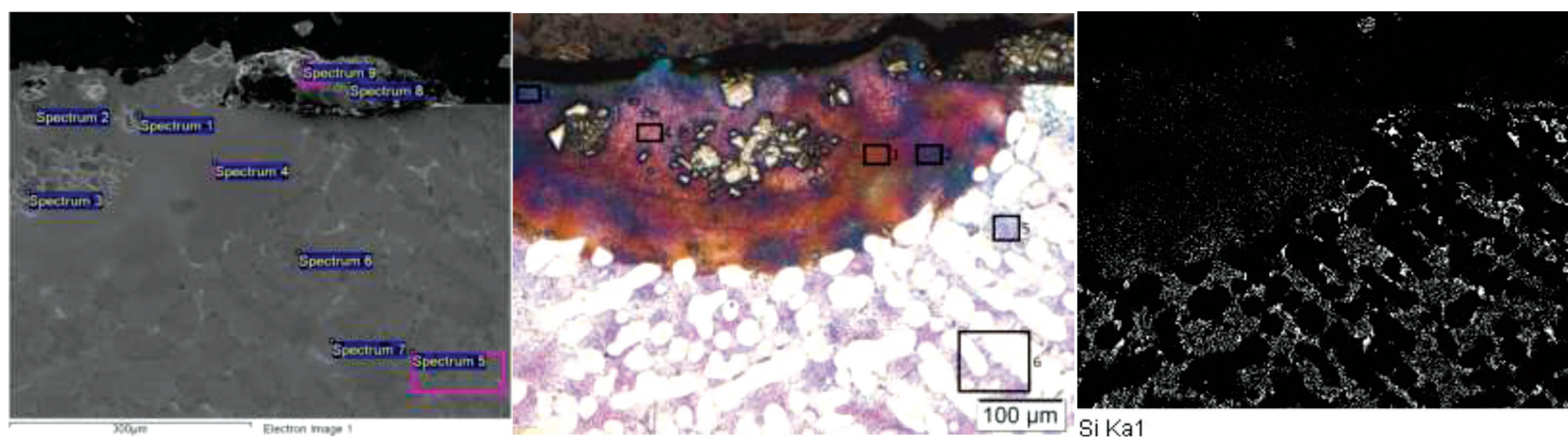

Figure 3: a) FE-SEM/EDS analyses of laser-modified Al alloy, non-etched, b) Microstructure after chemical etching using Weck's reagent (LM). Areas of microhardness measurements are designated. $E E D V=107 \mathrm{~J} / \mathrm{mm}^{3}$, c) X-ray map of Si in FE-SEM region of interest 


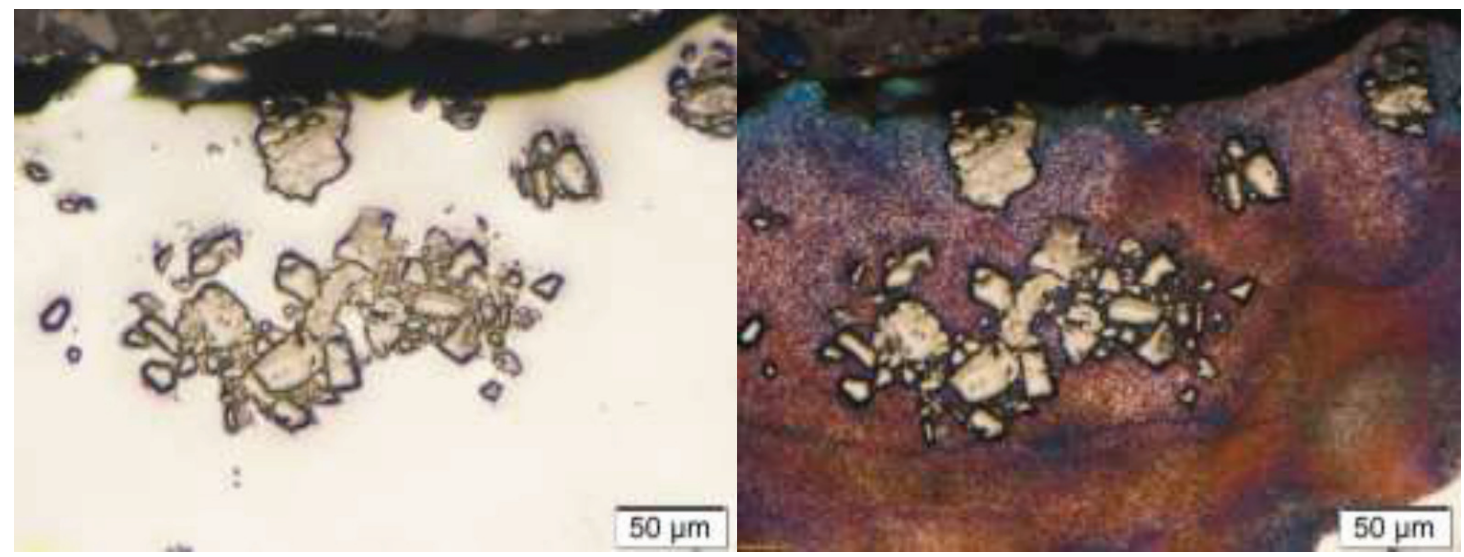

Figure 4: a) An enlarged section of the discontinuity section of a laser-clad layer before etching, b) after color etching. $E E D V=107 \mathrm{~J} / \mathrm{mm}^{3}$.

ure 3b also result in different colors and Vickers microhardnesses. They are listed in Table 5.

Table 4: EDS analyses of the selected points and areas from Figure 3a

\begin{tabular}{|c|c|c|c|c|c|c|c|c|}
\hline $\begin{array}{c}\text { Spec- } \\
\text { trum }\end{array}$ & $\mathrm{B}$ & $\mathrm{C}$ & $\mathrm{O}$ & $\mathrm{Mg}$ & $\mathrm{Al}$ & $\mathrm{Si}$ & $\mathrm{Ti}$ & $\mathrm{Cu}$ \\
\hline 1 & 37.65 & 3.11 & - & - & 0.53 & - & 58.71 & - \\
\hline 2 & 36.86 & 3.09 & - & - & 0.37 & - & 59.68 & - \\
\hline 3 & 34.44 & - & - & - & 0.31 & - & 65.24 & - \\
\hline 4 & - & 2.08 & - & 1.31 & 82.20 & 13.62 & - & 0.79 \\
\hline 5 & - & 1.65 & 0.91 & 1.37 & 86.20 & 8.63 & - & 1.24 \\
\hline 6 & - & - & 0.96 & - & 63.24 & 35.04 & - & 0.77 \\
\hline 7 & - & - & 0.67 & 0.41 & 96.55 & 1.77 & - & 0.60 \\
\hline 8 & 36.07 & 3.30 & - & - & 0.23 & - & 60.40 & - \\
\hline 9 & 32.60 & 10.83 & 3.26 & - & 23.49 & 1.32 & 28.50 & - \\
\hline
\end{tabular}

Table 5: Vickers microhardness of the designated areas from Figure $3 \mathbf{b}$

\begin{tabular}{|c|c|c|c|}
\hline Area & Microhardness & $\mathrm{Si}(w / \%)$ & Color \\
\hline 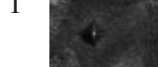 & $210 \mathrm{HV} 0.05$ & / & Red-brown \\
\hline 2 & $185 \mathrm{HV} 0.05$ & 13.62 & Marine-blue \\
\hline 3 & $183 \mathrm{HV} 0.05$ & / & Violet \\
\hline 48 & $163 \mathrm{HV} 0.05$ & / & Light Violet \\
\hline 5 & $135 \mathrm{HV} 0.05$ & 35.04 & Light Blue \\
\hline 6* & $120 \mathrm{HV} 0.3$ & 8.63 & $\begin{array}{l}\text { White - } \\
\text { Light Violet }\end{array}$ \\
\hline
\end{tabular}

*Matrix, not affected by laser. Out of site of Figure 4b
The softest part of the analyzed microstructure is the base material that is not affected by the laser surface treatment (120 HV 0.3). Here, a slightly harder microstructure component is at site 5 in Figure $\mathbf{3 b}$, where a remarkable silicon segregation was detected (see Table 4 - Spectrum 6). On the other hand, the semi-hemispherically created melt pool is much harder. Due to the moving heat source, the hardness depends on the local solidification parameters. High thermal gradients occurring during the laser pulses with a high power density lead to fine distributed and hard structures. ${ }^{5}$ The microhardnesses range from 185 to $210 \mathrm{HV} 0.05$, and that of the dilution zone is about $165 \mathrm{HV} 0.05$.

The effects of color etching shown in Figure 3b and 4b were also compared with the FE-SEM/EDS microanalyses of the polished sample. Surprisingly, a comparison of the EDS analyses, the X-ray map of Si and the color-etched images (Figure 3a to 3c) reveal that the bluish-colored parts of the microstructure might contain more Si. Using a comparison between the microchemical analyses of the selected points the silicon segregations are detected in the laser-melted area as well as in the base material, as seen from Figure 3a, Table 4, spectra 4 and 6, and Figure 3b, site 5. Similar to cast iron, ${ }^{22}$ the bluish colors represent a higher $\mathrm{Si}$ content in the laseraffected aluminum.

It can be seen that the laser-affected areas, i.e., the melt pool and its boundaries, can be better distinguished when using color etching. Moreover, the morphological texture of the previously scanned neighboring tracks $\mathrm{s}^{5}$ in the evolved microstructure can be followed. Selective color etching is more sensitive to morphological differences and compositional gradients; therefore, the accuracy of the metallographic analysis compared to the gray-scale etchings can be improved. ${ }^{22}$

After applying the chemical etching with Weck's reagent the melting pool, the penetration depth as well as various microstructure inhomogeneities are selectively tinted (Figure 4b).

The penetration depth was about $0.250 \mathrm{~mm}$. The microstructure of the penetration zone can be roughly 
divided into the following areas: area of the dilution substrate, melted substrate, and heat-affected zone between the penetration zone and the substrate. ${ }^{23}$ The color differences in the surrounding regions of the melt pool can be ascribed to the micro-segregation-sensitive nature of Weck's reagent. ${ }^{24,25}$ Outside the melt pool, the dendritic nature of the initial microstructure is seen. The shape of the melt pool is determined using three different isotherms: a) the liquidus temperature of the substrate material ahead of the laser beam, as the substrate has to be melted to ensure a metallurgical bond; b) the liquidus temperature of the coating material; and c) the solidus temperature of the coating material. ${ }^{26}$ The color etchants are reagents that remove a thin layer from the surface of the specimen and simultaneously dissolve it, leaving a thin film on the surface..$^{20}$ In the case of aluminum alloys the growth of the film is strongly influenced by the solute micro-segregations. The addition of different solutes can also affect the surface chemical reactions and, therefore, the colors change as a result. ${ }^{24,25}$ Since Al and various alloying elements as well as the selected cladding powders have significant differences in their chemical and physical properties, the interface region and the laser-melted regions display an inhomogeneous composition that is consistent with previous scientific reports by Wang et al. ${ }^{10,11}$

Color etching is very well suited to characterizing laser-surface-modified aluminum specimens. It can be recommended as a valuable step in the metallographic analysis of laser-melted aluminum specimens.

\section{CONCLUSIONS}

An AlSi12CuNiMg alloy substrate was surface modified using pulsed-laser cladding with a ceramics mixture of $\mathrm{TiC} / \mathrm{TiB}_{2} / \mathrm{Al}$ to increase the hardness of the surface layer.

The effect of the pulsed laser's effective energy density per volume of pre-pasted powder, i.e., 87-146 $\mathrm{J} / \mathrm{mm}^{3}$, on the characteristics of the $\mathrm{TiC} / \mathrm{TiB}_{2}$ laser clads was investigated, and the following conclusions were drawn:

The average thickness of the laser-cladded layer is around $0.1 \mathrm{~mm}$, in the range between $0.035 \mathrm{~mm}$ and $0.145 \mathrm{~mm}$. The average thickness of the melted aluminum beneath the laser-cladded layer is around 0.15 $\mathrm{mm}$, in the range between $0.05 \mathrm{~mm}$ and $0.220 \mathrm{~mm}$. The increasing of the EEDV influences larger scattering of the cladded-layer thickness, whereas the decreasing of the EEDV influences the decrease of its surface roughness. An improvement in the surface mechanical properties was achieved. The average hardness of the 0.1-mm-thick layer was 400 $\pm 10 \mathrm{HV} 0.3$.

In addition, color chemical etching using Weck's reagent was performed to study the sensitivity of the etchant to microstructure inhomogeneities of the lasertreated aluminum alloy. Color etching using Weck's reagent was shown to be a very sensitive qualitative metallographic tool. It highlights many details of the laser-affected areas.

The penetration depth, melting pool, their boundaries and various morphological and compositional inhomogeneities could be clearly distinguished. The sensitivity of the used color etchant to the morphological and compositional differences was confirmed by FE-SEM/EDS analyses and microhardness measurements. The silicon segregations in laser-affected aluminum are colored with bluish colors.

This additional information suggests that the method can be used for metallographic characterization in combination with more expensive and sophisticated analytical methods.

\section{Acknowledgments}

This work was carried out within the framework of the programs P2-0132 and P2-0270 of the Slovenian Research Agency, whose financial support is gratefully acknowledged. Authors gratefully acknowledge Mr. Janez Sušnik, PhD for performing the experimental part of the laser cladding.

\section{REFERENCES}

${ }^{1}$ J. Mazumder, Laser heat treatment: The state of the art, JOM 35 (1983), 18-26

${ }^{2}$ L. R. Katipelli, A. Agarwal, N. B. Dahotre, Laser surface engineered TiC coating on 6061 Al alloy: microstructure and wear, Appl. Surf. Sci. 153 (2000), 65-78, doi:10.1016/S0169-4332(99)00368-2

${ }^{3}$ M. M. Pariona, V. Teleginski, K. dos Santos, E. L. R. dos Santos, A. A. de Oliveira Camargo de Lima, R. Riva, AFM study of the effects of laser surface remelting on the morphology of Al-Fe aerospace alloys, Mat. Char. 74 (2012), 64-76, doi:10.1016/j.matchar.2012. 08.011

${ }^{4}$ L. Thijs, K. Kempen, J. P. Kruth, J. Van Humbeeck, Fine-structured aluminium products with controllable texture by selective laser melting of pre-alloyed AlSi10Mg powder. Acta Mat. 61 (2013), 1809-1819, doi:10.1016/j.actamat.2012.11.052

${ }^{5}$ L. M. Laorden, P. Rodrigo, B. Torres, J. Rams, Modification of microstructure and superficial properties of A356 and A356/10\%SiCp by Selective Laser Surface Melting (SLSM), Surf. Coat. Tech., 309 (2017), 1001-1009, doi:10.1016/j.surfcoat.2016. 10.046

${ }^{6}$ R. Šturm, M. Štefanikova, D. Steiner Petrovič, Influence of preheating on the surface modification of powder-metallurgy processed cold-work tool steel during laser surface melting, Appl. Surf. Sci. 325 (2015), 203-210, doi:10.1016/j.apsusc.2014.11.050

${ }^{7}$ J. R. Lawrence, D. G. Waugh, (Ed.), Laser surface engineering, 1st ed., Processes and Applications, Woodhead Publishing, Amsterdam 2015, 1-718

${ }^{8}$ A. Buling, H. Sändker, J. Stollenwerk, U. Krupp, A. Hamann-Steinmeier, Laser surface pretreatment of 100Cr6 Bearing Steel Hardening effects and white etching zones, Appl. Surf. Sci. 378 (2016), 564-571, doi:10.1016/j.apsusc.2016.03.088

${ }^{9}$ I. Maskery, N. T. Aboulkhair, M. R. Corfield, C. Tuck, A. T. Clare, R. K. Leach, R. D. Wildman, I. A. Ashcroft, R. J. M. Hague, Quantification and characterization of porosity in selectively laser melted Al-Si10-Mg using X-ray computed tomography, Mat. Char. 111 (2016), 193-204, doi:10.1016/j.matchar.2015.12.001 


\section{STEINER PETROVIČ, R. ŠTURM: SENSITIVITY OF WECK'S REAGENT TO THE MICROSTRUCTURE INHOMOGENEITIES ...}

${ }^{10}$ A. H. Wang, C. S. Xie, J. H. Nie, Bond strength of a laser-clad ironbase alloy coating on Al-Si alloy substrate and its fracture behavior, Mat. Char. 47 (2001), 1-7, doi:10.1016/S1044-5803(01)00145-0

${ }^{11}$ A. H. Wang, C. S. Xie, W. Y. Wang, Cracking behavior in the transitional region of laser-clad coatings on Al-Si alloy under multiple impact loading, Mat. Char. 49 (2003), 247-254, doi:10.1016/ S1044-5803(03)00014-7

${ }^{12}$ J. A. Varela, J. M. Amado, M. J. Tobar, M. P. Mateo, A. Yañez, G. Nicolas, Characterization of hard coatings produced by laser cladding using laser-induced breakdown spectroscopy technique, Appl. Surf. Sci. 336 (2015), 396-400, doi:10.1016/j.apsusc.2015. 01.037

${ }^{13}$ M. Barekat, R. S. Razavi, A. Ghasemi, Nd:YAG laser cladding of Co-Cr-Mo alloy on $\gamma$-TiAl substrate, Opt. Laser Technol. 80 (2016), 145-152, doi:10.1016/j.optlastec.2016.01.003

${ }^{14}$ K. Zhang, J. Zou, J. Li, Z. Yu, H. Wang, Surface modification of TC4 Ti alloy by laser cladding with TiC+Ti powders, Trans. Nonferrous Met. Soc. China 20 (2010), 2192-2197, doi:10.1016/S1003-6326 (09)60441-6

${ }^{15}$ R. Anandkumar, A. Almeida, R. Vilar, Wear behavior of Al-12Si/ TiB2 coatings produced by laser cladding, Surf. Coat. Tech., 205 (2011), 3824-3832, doi:10.1016/j.surfcoat.2011.01.048

${ }^{16}$ R. Anandkumar, A. Almeida, R. Vilar, Microstructure and sliding wear resistance of an $\mathrm{Al}-12 \mathrm{wt} \% \mathrm{Si} / \mathrm{TiC}$ laser clad coating, Wear, 282-283 (2012), 31-39, doi:10.1016/j.wear.2012.01.022

${ }^{17}$ D. Ravnikar, N. B. Dahotre, J. Grum, Laser coating of aluminum alloy EN AW 6082-T651 with TiB2 and TiC: Microstructure and mechanical properties, Appl. Surf. Sci. 282 (2013), 914-922, doi:10.1016/j.apsusc.2013.06.089

${ }^{18}$ Y. Diao, K. Zhang, Microstructure and corrosion resistance of TC2 Ti alloy by laser cladding with $\mathrm{Ti} / \mathrm{TiC} / \mathrm{TiB}_{2}$ powders, Appl. Surf. Sci. 352 (2015), 163-168, doi:10.1016/j.apsusc.2015.04.030
${ }^{19}$ J. Sušnik, J. Grum, R. Šturm, Effect of pulse laser energy density on TiC cladding of aluminium substrate, Teh. Vjes., 22 (2015), 1553-1560, doi:10.17559/TV-20150221215735

${ }^{20}$ A. Farnia, F. M. Ghaini, J. Sabbaghzadeh, Effects of pulse duration and overlapping factor on melting ratio in preplaced pulsed Nd:YAG laser cladding, Opt. Lasers Eng. 51 (2013), 69-76, doi:10.1016/ j.optlaseng.2012.07.015

${ }^{21}$ C. K. Sahoo, M. Masanta, Effect of pulse laser parameters on TiC reinforced AISI 304 stainless steel composite coating by laser surface engineering process, Opt. Lasers Eng. 67 (2015), 36-48, doi:10.1016/j.optlaseng.2014.10.010

${ }^{22}$ S. Vazehrad, J. Elfsberg, A. Dioszegi, Study of microstructure and silicon segregation in cast iron using color etching and electron microprobe analysis, Mat. Char. 104 (2015), 132-138, doi:10.1016/ j.matchar.2014.09.008

${ }^{23}$ A. Riquelme, P. Rodrigo, M. D. Escalera-Rodriguez, J. Rams, Analysis and optimization of process parameters in Al-SiCp laser cladding, Opt. Lasers Eng. 78 (2016), 165-173, doi:10.1016/ j.optlaseng.2015.10.014

${ }^{24}$ L. Gao, Y. Harada, S. Kumai, Microstructural characterization of aluminium alloys using Weck's reagent, part I: Applications, Mat. Char. 107 (2015), 426-433, doi:10.1016/j.matchar.2015.01.005

${ }^{25}$ L. Gao, Y. Harada, S. Kumai, Microstructural characterization of aluminium alloys using Weck's reagent, part II: Coloring mechanism, Mat. Char. 107 (2015), 434-452, doi:10.1016/j.matchar. 2015.05.006

${ }^{26}$ R. Vilar, E. C. Santos, P. N. Ferreira, N. Franco, R. C. da Silva, Structure of NiCrAlY coatings deposited on single-crystal alloy turbine blade material by laser cladding, Acta Mat., 57 (2009), 5292-5302, doi:10.1016/j.actamat.2009.06.049 